\title{
VAT and agriculture: lessons from Europe
}

\author{
Sijbren Cnossen ${ }^{1}$
}

Published online: 18 May 2017

(C) The Author(s) 2017. This article is an open access publication

\begin{abstract}
Little has been written about the treatment of agriculture under the value added tax (VAT). This article attempts to fill the void by surveying and evaluating the situation in the Member States of the European Union (EU) and some other countries. Farmers are often exempted from VAT for administrative and political reasons. But this means that the VAT on their inputs cannot be 'washed out' through the tax deduction/credit mechanism. It then has to be borne by the farmers themselves or becomes an indeterminate and capricious element in consumer prices. To compensate farmers for the uncompensated VAT on inputs, the EU has devised a flat-rate scheme that permits them to charge a presumptive rate (approximately equal to the effective VAT rate on sector-wide inputs) on their sales to taxable agro-processing firms which, in turn, are permitted to take a deduction for this flat-rate addition from the VAT on their sales. Obviously, the flat-rate scheme is an arbitrary way of trying to achieve equal treatment between exempt and taxable farmers and between exempt farm products and other taxable goods and services. Full taxation, subject to the general threshold, appears to be the preferred choice.
\end{abstract}

Keywords VAT · Agriculture - European Union · Flat-rate compensation scheme · Reduced rates $\cdot$ Incidence

JEL Classification $\mathrm{H} 22 \cdot \mathrm{H} 25$

CPB Netherlands Bureau for Economic Policy Analysis and Professor of Economics at the University of Pretoria; Professor Emeritus of Erasmus University Rotterdam and University of Maastricht.

$\bowtie \quad$ Sijbren Cnossen

cnossen@ese.eur.nl

1 CPB Netherlands Bureau for Economic Policy Analysis, The Hague, The Netherlands 


\section{Introduction}

In the 1960s, when the value added tax (VAT) was introduced in the European Union, it was considered very difficult, for administrative and political reasons, to include farmers (agriculture) in the ambit of the VAT. ${ }^{1}$ Many farmers were small and held few if any accounts of their transactions, while their political clout was substantial. But exempting farmers from registering for and paying VAT meant that the VAT paid on farm inputs either entered into the price charged to taxable agro-processing firms or reduced the trading margins of the farmers themselves-depending on elasticities of supply and demand. If the VAT on inputs entered into the price, it would most likely cascade throughout the production-distribution process and have an indeterminable and capricious effect on ultimate consumer prices. If it reduced the disposable income of farmers, it would be a regressive form of taxation imposed on mostly low-income groups.

In either case, the result was considered unacceptable and a way had to be found to relieve exempt farmers of the VAT on their inputs without requiring them to register for VAT. To achieve this, the European Union (EU) devised a unique flat-rate scheme that allowed farmers to apply a flat rate to their sales to taxable processing firms and add the amount to the invoice accompanying their supplies to processing firms. This rate, set by the government, represented the effective VAT rate on total taxable inputs of the exempt agricultural sector. ${ }^{2}$ Farmers were allowed to keep the amount thus calculated as compensation for the VAT on their inputs, while agro-processing firms could deduct it from the VAT on their sales. Alternatively, but equivalently, processing firms were allowed to deduct a similar presumptively determined amount from their VAT on sales, which they were assumed to pay out to farmers. In either case, farmers did not have to file VAT returns or keep a record of their VAT on purchases. This scheme would wash out the VAT on farm inputs on average, but not on a farm-by-farm or product-by-product basis. Accordingly, its effects are arbitrary and distortionary, influencing, among others, input choice.

Half a century has elapsed since the introduction of the flat-rate scheme. In the meantime, the scheme or, for that matter, the treatment of agriculture has not received much attention in the literature on tax, although the food sector is an important part of many economies. After an early full treatment by Tait (1988, chapter 7), Ebrill et al. (2001, chapter 9) provide a general overview of the issues, but Bird and Gendron (2007), Ecker et al. (2012) and Schenk et al. (2015) do not deal with the VAT treatment

\footnotetext{
1 Unless the context provides otherwise, forestry and fisheries are not dealt with in this article, although the VAT situation regarding these activities resembles that of agriculture.

2 If the input VAT is calculated on a VAT-exclusive basis, it has to be converted into a tax-inclusive basis when applied to farm sales since the latter include the VAT on inputs. This can be done by applying the formula $t_{e}=t_{i} /\left(1-t_{i}\right)$ in which $t_{e}$ is the VAT-exclusive rate and $t_{i}$ the VAT-inclusive rate.
} 
of agriculture in their books on the VAT. ${ }^{3}$ At the same time, much experience has been gained with the application of the VAT to the agricultural sector in countries in as well as outside the EU. Interestingly, the flat-rate scheme has not been adopted by any non-EU country, perhaps because of its uneven effects. Further, the thinking about the design principles of a best-practice VAT has evolved, particularly since the introduction of such a VAT in New Zealand and various other latecomers to the VAT. In light of these developments, the question arises of whether or not the current arrangements in the EU Member States are still satisfactory.

Against this background, this article surveys and evaluates the application of the VAT to the agricultural sector in the Member States of the EU and some other countries. This is done by reference to the design principles of a best-practice VAT as developed in the tax literature and generally applied in countries such as Australia, Canada, New Zealand, Singapore and South Africa.

\subsection{Design principles of a best-practice VAT}

To begin with, it is widely agreed that a best-practice VAT is primarily intended to raise revenue, predictably and efficiently. The VAT differs from the excise taxes in that it is not intended to internalize external costs or change people's behavior, and from the import duties in that it should not be used to support trade policy. It differs from the income tax in that it is not the instrument of first choice to influence the tax burden distribution or to stimulate industry through investment incentives. The income tax and the social benefit system are much better tax-and-expenditure instruments to address the regressivity of the overall tax system. And investment incentives, if considered desirable, should be incorporated in taxes on profits, because they purport to raise the net return on investment. In short, under the VAT, the primary goal should be revenue and revenue alone. That revenue can be used, of course, to finance pro-poor expenditure programs on, say, education and health care.

The major design principle that follows from this view on the role of the VAT is that it should tax all goods and services used or consumed in the country equally at a uniform rate. Exemptions should be restricted to those absolutely necessary on administrative grounds, including a threshold for small farmers (and other small businesses), whose compliance and administrative costs tend to be disproportionately high in relation to turnover. Otherwise, a broad base and a single rate are indicated since they distort the efficient allocation of resources brought about by the market as little as possible. ${ }^{4}$ Admittedly, the EU (and national governments) interferes heavily in agricultural markets, among others through the Common Agricultural Policy (CAP), ${ }^{5}$

\footnotetext{
3 Although Bird and Gendron (2007) indicate that they do not discuss the subject (p. 81), they do make some useful comments on the Ukrainian situation (pp. 124-125). The subject index in Schenk et al. (2015) does not refer to 'agriculture' or 'farming'.

4 For a concise, balanced treatment, see Keen (2013).

5 The four basic EU regulations defining the new Common Agricultural Policy can be found in the Official Journal of the European Union of 20 December 2013. Basically, the CAP is an income support policy in the form of direct payments, known as the single payment scheme, 'to ensure a decent standard of living for farmers, to provide a stable and safe food supply chain at affordable prices for consumers, and to ensure the
} 
but adding a VAT-induced distortion is unlikely to improve the situation. Accordingly, neutrality (meaning that relative prices should not change on account of the VAT) remains a prominent lodestar in VAT design.

On this basis, the following considerations are relevant for the VAT treatment of the agricultural sector:

- In principle, farmers, agro-processing firms and traders in food products should be taxed the same as other manufacturing and trading establishments if their sales exceed the registration threshold below which potentially taxable persons do not have to file returns and pay VAT. This means that their output should be subject to the standard rate, that they should be able to deduct the VAT on inputs from the VAT on output and that they should remit the net VAT to the government or receive a refund if the VAT on inputs exceeds the VAT on output.

- The neutrality criterion also implies that agricultural products entering intra-EU and international trade should be treated on a destination basis - that is, taxed in the country of consumption rather than the country of production. In other words, exports should leave a country free of VAT, while imports should be taxed on a par with domestically produced goods. In short, the VAT should not be used to protect domestic agriculture or to subsidize exports. ${ }^{6}$

- Farmers whose output (turnover) is less than the registration threshold do not have to register for the VAT, although they can elect to do so. Consequently, they cannot charge VAT to their customers, nor deduct the VAT charged by registered suppliers. For administrative (or political) reasons, the exemption from registration can be extended to the whole agricultural sector as is possible under the Common VAT Directive (2016) in the EU.

- Farmers incur costs in complying with the VAT by having to register for VAT or by electing to do so. These costs tend to be distributed regressively with respect to income: as a percentage of income (or turnover), on average, small farmers (with inadequate accounts) incur higher costs than large farmers (with proper books of account). ${ }^{7}$ Exempt farmers do not incur compliance costs but are faced with nondeductible VAT on inputs.

\section{Footnote 5 continued}

development of rural areas throughout the EU' (Eurostat 2016, p. 8). For details of the budgetary expenditure on the CAP, see European Union (2013, table 3.4.1). The EU also has a Common Fisheries Policy but not a Common Forestry Policy.

6 This was possible under the previous turnover taxes levied in five of the six founding Member States, because the precise refund at export and the precise compensating rate at import were unknown. That the VAT, or rather indirect taxation, should not be used to support trade policy has a legal basis in Article 110 of the Treaty on the Functioning of the European Union (TFEU) (European Union 2008) as well as in Article III of the General Agreement on Tariffs and Trade (GATT 1986) as superseded by the World Trade Organization's treaty (WTO 1994) of which all EU Member States are members in their own right as is the European Union.

7 See Cnossen (1994) and Evans (2008) for the evidence. Cnossen (1994) notes that 'all studies emphasize that the compliance costs of the VAT, as a percentage of sales, fall with exceptional severity on small businesses'. As calculated in World Bank / PriceWaterhouseCoopers (2016), persons taxable for VAT in EU countries spend on average $56 \mathrm{~h}$ annually on meeting their VAT obligations. More than $80 \mathrm{~h}$ are spent in Slovakia (84), Portugal (90), Czech Republic (94), Hungary (96), Poland (98), Belgium (100) and Bulgaria (165). By comparison, the time annually spent on VAT obligations in countries with a best-practice VAT is 
- If exempt farmers cannot or do not have to comply with the VAT, an effort should be made to eliminate the VAT on their inputs so that it does not have to be borne by them nor become an arbitrary element of tax in product prices. Taxing inputs of agricultural products without relief through the VAT mechanism means that these products are possibly discriminated against compared with other domestically produced goods and services, or against similar imported products which enter the country presumptively free of VAT on inputs. Arguably, relief is not necessarily called for if farm produce is sold at the farm gate or to exempt traders in local markets, because the full VAT (assuming this to be the standard rate, not some zero rate) would have been paid on foodstuffs sold through taxable trading channels.

\subsection{Organization of the article}

The article proceeds with a brief review, in Sect. 2, of some pertinent statistics of the agricultural sector in the EU, highlighting features that have a bearing on the design of an appropriate VAT regime for the sector. As shown in Sect. 3, such a regime can be in the form of either a (regular) 'taxation regime' or an (exceptional) 'exemption regime', both supplemented by measures to relieve exempt farmers of the VAT on inputs. Section 4 discusses the taxation regimes in various EU Member States as well as some other countries. Section 5 does the same for the exemption regime-that is, the common flat-rate scheme in the EU. On the basis of a comparative analysis, Sect. 6 then attempts to distill the preferred choice from the survey. Finally, the ultimate taxation of agricultural produce is also related to the VAT treatment of foodstuffs bought by consumers. Accordingly, Sect. 7 lists the arguments for and against the application of the standard rate to foodstuffs. Section 8 briefly concludes.

\section{Agriculture in the European Union}

According to Eurostat's 2015 edition of Agriculture, Forestry and Fishery Statistics (Eurostat 2016), there are some 11 million farms in the 28 Member States of the EU employing over 22 million people. ${ }^{8}$ As shown in Table 1, this represents slightly over $5 \%$ of total employment and generates $1.2 \%$ of the EU's gross domestic product (GDP). ${ }^{9}$ With a further 4 million people working in the food industry, ${ }^{10}$ the farming

\footnotetext{
Footnote 7 continued

the following: Singapore (30), Australia (50), Canada (50), South Africa (55) and New Zealand (59). For a comprehensive review of the literature on VAT compliance costs, see Barbone et al. (2012).

8 Unless indicated otherwise, all statistics in this section are from European Union (2013) and Eurostat (2016).

9 These figures include relatively small numbers of employment and output of forestry, hunting and fishing. The relative weight of agriculture, forestry and fisheries in the EU-28 economy has been declining over the last 50 years. From 2000 to 2014, the share of agriculture, forestry and fisheries in the EU's total GDP fell from 2.2 to $1.6 \%$ (Eurostat 2016, p. 8). From 1983 to 2013, four in every five farms with dairy cows stopped operating in the EU (Eurostat 2016, p. 18).

10 According to the European Commission (2014), numbers of establishments in the food industry are some 250,000 food manufacturers, 200,000 food wholesalers and 500,000 food retailers.
} 
and food sectors together provide $7 \%$ of all jobs and generate $6 \%$ of the EU's GDP. Accordingly, the VAT treatment of these sectors matters. Of further interest is that the EU, although a net importer of food, is also a major exporter of quality food, accounting for nearly $7 \%$ of all exports. That the average EU family spends around $16 \%$ of its monthly disposable income on food is another relevant fact for VAT design purposes.

These averages hide important differences between the Member States. In Romania, for instance, employment in agriculture accounts for nearly $31 \%$ of total employment in the country, while agriculture contributes nearly 5\% of GDP. By contrast, merely $2.4 \%$ of the Danish labor force works in agriculture, while the sector contributes only $1.5 \%$ of GDP, but nevertheless it accounts for one-fifth of the country's exports. In Denmark, it is therefore important that exports are fully freed of VAT. Further, the VAT treatment of foodstuffs is of significance in Estonia and Latvia, where households spend on average slightly more than one-fourth of their consumption expenditures on foodstuffs against an average of around $16 \%$ in the EU. ${ }^{11}$

Of the 10.8 million farm holdings in the EU, one-third or 3.6 million are located in Romania, while another one-fifth can be found in Poland $(13.2 \%$ of the EU's total) and Italy (9.3\%). Most farms are small, very small. The size of over $43 \%$ of all farms in the EU does not exceed 2 hectares and close to two-thirds of all farms are smaller than 5 hectares. Such small farms are particularly prevalent in Malta, Romania, Cyprus, Bulgaria, Hungary and Greece, where they represent more than three-quarters of all farms. Usually, the standard output of these farms does not exceed $€ 2000$ and together they contribute only $1 \%$ of total agricultural output. This highlights the importance of the role of the VAT threshold in avoiding undue compliance and administrative costs. Further, as shown in Table 1, the average area per holding is merely 16 hectares, while only $3 \%$ of all farms are 100 hectares or larger - in sharp contrast to the situation in countries such as the USA and Canada. Interestingly, the $2.4 \%$ of all holdings that had a standard output in excess of $€ 250,000$ account for more than half (51.7\%) of all agricultural economic output.

Total output of the agricultural sector in 2014 was estimated at $€ 415$ billion at producer prices. ${ }^{12}$ France and Germany are the biggest producers by far in the EU, between them accounting for $37 \%$ of cereals output by volume, $31 \%$ of all livestock and $34 \%$ of all dairy cows, estimated at 24 million head for the EU as a whole. As Table 1 shows, France's output surpasses Germany's in these fields, except in the

\footnotetext{
11 In Estonia and Latvia, food is generally taxed at the standard rate of 20 and $21 \%$, respectively, which contributes to the high share of expenditure on food in disposable income. Other EU Member States where the share of food in total consumption expenditures exceeds $20 \%$ are: Bulgaria (26.6\%), Poland (25.3\%), Hungary (24.7\%), Czech Republic (23.9\%), Slovakia (22.3\%), Greece (20.6\%), Slovenia (20.4\%) and Portugal (20.3\%). Obviously, the relatively low incomes in these countries are the main explanatory variable for these relatively high shares of food in total expenditures. By contrast, the share of expenditures on food in high-income Danish households, which are confronted with a 25\% VAT rate, is merely $14.9 \%$.

12 Seven Member States account for around three-quarters of total agricultural output by value: France $(18 \%)$, Germany (14\%), Italy (13\%), Spain (10\%), the UK (8\%), the Netherlands $(7 \%)$ and Poland $(5 \%)$.
} 
Table 1 European Union: agricultural indicators and characteristics, latest years. Source: Agricultural indicators-European Union, 2013, tables 2.0.1.2, 2.0.1.3, 3.1.3 (intermediate inputs), 3.5.1.4 (women's employment) and 6 (factor income). Agricultural characteristics-Eurostat, 2016, tables 1.2, 2.1, 2.2, 2.8, 2.9, 3.1, 4.1, 5.7, 5.8, 6.1 and 7.2. Employment under agricultural indicators includes employment in forestry, hunting and fishing

Percent of total in EU or by country (unless otherwise indicated)

$\begin{array}{llll}\text { Highest/largest } & & \text { Next highest/largest } \\ { } \% \text { \%other } } & \text { Country } \quad \% \text { other }\end{array}$

Agricultural indicators (EU-27)

Agriculture in GDP (\%)

Agriculture in employment (\%)

Agro-food exports (\% of total)

Agro-food imports (\% of total)

Expenditures on food (\% of total)

Agricultural characteristics (EU-28)

Farms

$$
\begin{aligned}
& \text { Number of holdings }(000) \\
& >0 \text { and }<2 \text { ha ( } \% \text { of total) } \\
& >0 \text { and }<5 \text { ha ( } \% \text { of total) } \\
& \geq 100 \text { ha ( } \% \text { of total) }
\end{aligned}
$$

Average area per holding (ha)

Production

Output at producer prices ( $€$ million)

Cereals (000 tonnes)

Livestock (000 units)

Dairy cows (000 head)

Cows' milk (000 tonnes)

Employment

Total regular workers (000)

Annual work units (000)

Family labor force (\%)

Women (\%)

Factor income per AWU

Intermediate inputs

Total as $\%$ of value of output

Seed, feed, vets ( $\%$ of total)

Fertilizers, pesticides ( $\%$ of total)

Energy (\% of total)

Environment

Greenhouse gases (\% of total)

Ammonia emissions (000 tonnes)

Forestry and fisheries

Forests (000 ha)

\begin{tabular}{|c|c|c|c|c|}
\hline 415,055 & France & 73,994 & Germany & 57,637 \\
\hline 334,182 & France & 72,715 & Germany & 52,010 \\
\hline 130,319 & France & 21,871 & Germany & 18,407 \\
\hline 3,557 & Germany & 4296 & France & 3697 \\
\hline 159,641 & Germany & 32,381 & France & 25,780 \\
\hline 2,210 & Romania & 6578 & Poland & 3559 \\
\hline 509 & Poland & 1919 & Romania & 1553 \\
\hline 76.5 & Poland & 93.8 & Slovenia & 93.7 \\
\hline 25.4 & Greece & 33.5 & Poland & 31.9 \\
\hline 2,591 & Denmark & 52,737 & UK & 38,985 \\
\hline 60.7 & Slovenia & 78.8 & Ireland & 75.0 \\
\hline 6.7 & Slovenia & 60.6 & Belgium & 60.4 \\
\hline 12.3 & Lithuania & 19.1 & Latvia & 18.9 \\
\hline 12.2 & Greece & 26.9 & Bulgaria & 22.6 \\
\hline 10.3 & Ireland & 30.8 & Lithuania & 23.6 \\
\hline 3591 & France & 701 & Germany & 633 \\
\hline 61,081 & Sweden & 28,073 & Finland & 22,218 \\
\hline 1646 & Spain & 358 & UK & 196 \\
\hline
\end{tabular}

Fishing fleet (000 tonnes)

$\begin{array}{lllll}1.2 & \text { Romania } & 4.7 & \text { Bulgaria } & 4.2 \\ 5.2 & \text { Romania } & 30.6 & \text { Bulgaria } & 18.9 \\ 6.8 & \text { Denmark } & 19.2 & \text { Latvia } & 18.9 \\ 5.7 & \text { Cyprus } & 16.7 & \text { Ireland/Latvia } & 14.3 \\ 16.5 & \text { Estonia } & 28.3 & \text { Latvia } & 27.3\end{array}$

$\begin{array}{lllll}\text { 10,841 } & \text { Romania } & 3630 & \text { Poland } & 1429 \\ 43.4 & \text { Malta } & 81.2 & \text { Cyprus } & 74.4 \\ 64.7 & \text { Malta } & 93.1 & \text { Romania } & 90.4 \\ 3.1 & \text { UK } & 21.9 & \text { Luxembourg } & 21.6 \\ 16.1 & \text { Czech Rep } & 133.0 & \text { UK } & 92.3\end{array}$




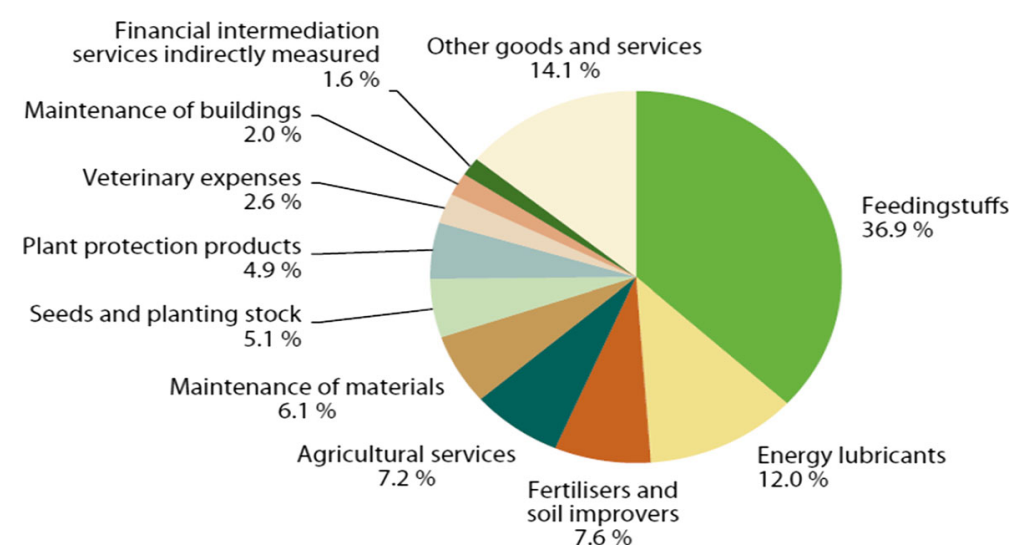

Fig. 1 European Union: intermediate inputs consumed by the agricultural sector at basic prices, 2014. Source: Eurostat 2016, p. 60

number of cows and in milk production. ${ }^{13}$ These agricultural data for the two largest core Member States of the EU illustrate the political importance of the VAT treatment of agricultural products.

All in all, 22.2 million people work regularly in agriculture or some 9.5 million on a full-time basis, denoted in annual work units (AWUs). The difference can be explained by the fact that much farm work is seasonal and that many farmers have their main employment in other economic sectors. In most EU Member States, farming is predominantly a family activity. On average, about three-quarters of full-time labor input is provided by the holder and members of his or her family, while family input is over $90 \%$ in several eastern EU Member States. Women provide on average onefourth of the full-time labor force on the farm, but this share is one-third in Greece and Poland. With farming becoming more and more mechanized and organized in larger holdings, agricultural labor input declined by one-quarter between 2005 and 2014.

Agricultural factor income is on average $€ 12,600$ in the EU compared with an economy-wide average of $€ 25,000$. Denmark's factor income of $€ 52,700$ from agriculture compares favorably with the factor incomes of $€ 5000$ or less in Slovenia, Poland, Bulgaria, Latvia, Croatia and Romania. The low factor incomes in many Member States indicate that exempt farmers should not be burdened by VAT on inputs and that compliance costs for taxable farmers should be kept to a minimum.

Important for the purpose of this survey is that more than $60 \%$ of the value of farm output consists of inputs, mainly feeding stuffs. Figure 1 has details on the composition of all farm inputs at basic prices (which differ from output values, shown in Table 1). Of special importance are the inputs of fertilizers, pesticides and fossil

13 Of the cows' milk produced on farms in the EU, $92 \%$ is distributed to dairies (from a low of $22 \%$ in Romania to $100 \%$ in Ireland, Malta and Sweden). Cheese accounts for $40 \%$ of all milk for dairy production, and drinking milk and milk used for the production of cream each for $13 \%$ of total dairy production. 
fuels, whose use can cause environmental degradation. These show up, among others, in the contribution of the agricultural sector to emissions of greenhouse gases (more than $30 \%$ of the country's total for Ireland, for instance). The three main sources of these emissions are agricultural soils (one-half of emissions), enteric fermentation (one-third) and manure management (one-sixth). Further, agriculture is responsible for $93 \%$ of total ammonia emissions in the EU. Ammonia increases the level of air pollution and, once deposited in water and soil, it can potentially cause acidification and eutrophication (oxygen depletion in water).

This review of the agricultural sector in the EU has various implications for VAT design.

- Two-thirds of all farm holdings are less than 5 hectares in size. It would seem obvious to exempt these farms based on size, but 5 hectares is more than enough land on which to operate an intensive farm raising hogs or chickens or on which to place greenhouses to grow fruits and vegetables. Accordingly, a threshold by reference to turnover should probably be preferred, but a combination of size and turnover would also be possible.

- Sixty percent of farm output by value consists of intermediate inputs. Preferably, the VAT on these inputs should not cumulate throughout the production-distribution process if farmers are exempt, either generally or by virtue of the threshold. Cumulative effects are particularly objectionable if exempt farmers supply, say, feedstuffs to other exempt or taxable farmers, or export their output. Optional registration is possible, but would saddle farmers with onerous compliance costs.

- Similarly, large (exporting) farms should not be confronted with hidden VAT in the inputs bought from exempt farmers, but be able to deduct the VAT on inputs from their suppliers in full.

- Inputs, such as chemical fertilizers and pesticides, whose use is harmful to the environment, should be subject to an excise that internalizes the external cost (water contamination, human and animal poisoning-diseases) that can be attributed to their use. ${ }^{14}$ Obviously, this excise should not be rebated at the export stage. Also, the VAT on these products should not be considered a substitute for the externalitycorrecting excise that ought to be imposed. Principally, VAT should be imposed on the excise-inclusive price of the products.

- Income support measures under CAP represent a compensating instrument in the EU's expenditure kit that can be used to mitigate the extra tax burden on small exempt farmers attributable to nondeductible input VAT or compliance costs.

14 Currently, excises on fertilizers and/or pesticides are levied in Belgium, British Columbia (Canada), Denmark, Finland, France, Italy, Louisiana (USA), the Netherlands and Norway. The rationale of these excises is to reduce the volume of toxic pesticides and fertilizer and promote the transition to low-toxicity alternatives. The World Health Organization has estimated that three million cases of pesticide poisoning occur every year, resulting in over 250,000 deaths. See the overview in UNDP (2017) and the in-depth analysis on their form, use and effects in Denmark, France, Norway, and Sweden in Böcker and Finger (2016). 
Box 1 Options for the VAT treatment of the agricultural sector (separate or in combination)

1. Taxation regime Farmers are treated like other businesses subject to VAT- that is, output is taxed and the tax on inputs is deductible from the tax on output. Small farmers whose output falls below the threshold are exempted but can elect to be registered

2. Exemption regime All or some categories of farmers are exempted from VAT regardless of turnover, but individual farmers can elect to be taxable

3. Input VAT relief for exempt farmers under either regime

(a) Exemption of agricultural inputs

(b) Reduced or zero rate on agricultural inputs

(c) Flat-rate scheme

(i) farmers charge a presumptive tax on output at a rate that on average accounts for the VAT on their inputs; they keep the amount of the presumptive tax, while taxable purchasers of farm products deduct the amount of the tax from their VAT on output

(ii) equivalent in result, farmers do not charge tax on output, but purchasers of farm products are permitted a presumptive tax deduction, which on average accounts for the VAT paid on inputs by farmers; they pay the amount of the deduction to farmers

(d) Monetary compensation by the government of the VAT paid on agricultural inputs on the basis of individual refund claims or calculated as under the flat-rate scheme

\section{Options for the VAT treatment of agriculture}

\subsection{Overview}

Basically, there are four practical ways, separately or in combination, in which VAT can be applied to the agricultural sector: (1) a taxation regime, (2) an exemption regime, (3) input VAT relief for exempt farmers, and, somewhat removed, (4) output VAT relief for farm products (see Box 1). Equal treatment vis-à-vis other goods and services (neutrality), is an important criterion in choosing between the alternatives. Neutrality implies that an effort should be made to eliminate the hidden input VAT of exempt farmers. Further, compliance costs, which, measured against income, tend to weigh more heavily on small taxable farms than on large farms, should be minimized.

In considering these options, it is assumed that at every stage the gross VAT on sales by taxable farmers is passed on in output prices and is deductible from the VAT on output of the taxable purchasers of their products. ${ }^{15}$ Accordingly, the VAT at the retail

15 This is the standard assumption, used, for instance, in Institute for Fiscal Studies et al. (2011) and OECD / Korea Institute of Public Finance (2014). IHS (2011) has an extensive discussion of the theoretical and empirical literature on pass-through. These studies note that in some cases the VAT may be less (or more) than fully passed on to the consumers. This note of caution is supported by the analysis of Benedek et al. (2015). On the basis of a large data set providing disaggregated monthly data on prices and VAT rates for 17 Eurozone countries over 1999-2013, these authors estimate that pass-through is less than full on average and differs markedly across types of VAT changes. Pass-through is about $100 \%$ for changes in the standard rate, but merely around $30 \%$ for changes in reduced rates and essentially zero for reclassifications. 
stage at which foodstuffs are sold to consumers equals the VAT times the consumer price net of VAT, which equals the total value added throughout the productiondistribution chain. Further, farmers who are not liable to VAT on output are assumed not to be able to pass the unrelieved tax on inputs on to the taxable purchasers of their products, except perhaps with respect to sales to exempt purchasers, mainly consumers, who are confronted with VAT-inclusive prices of similar taxable products.

\subsection{Review of alternatives}

Under the taxation regime, as indicated in Box 1, the agricultural sector is treated the same as any other taxable sector. The output of farmers and agro-processing firms attracts the standard VAT rate, and taxable businesses are entitled to deduct the VAT on inputs from the VAT on output and are obliged to remit the difference to the VAT office or receive a refund if the VAT on inputs exceeds the VAT on output. Producers whose turnover is below the threshold are exempted. Consequently, exempt producers are stuck with the VAT on their inputs, but they would be able to pass the input VAT on to their taxable customers if they exercise the option of registration and payment of VAT. They would then incur compliance costs, whose burden is akin to that of a tax.

It should be noted that the effects of the threshold on farmers differ from the effects on, say, small exempt retailers that sell to nonregistered consumers. Small retailers benefit from the exemption because their own value added (generally, the reward for their labor) is not taxed. This is also true with respect to farmers selling directly to consumers or exempt traders, but not to exempt farmers selling their products to taxable agro-processing firms (by definition, retailers do not sell to other taxable traders). These farmers would be stuck with the unrelieved VAT on inputs, which would likely have to be borne by them, because taxable farmers would be able to pass the VAT forward to other taxable stages of production and distribution. Accordingly, efforts to eliminate this unrelieved VAT in the agricultural sector tend to be an important issue, although relief does not have to be made available to exempt traders in the retail sector or, for that matter, to exempt farmers selling at the farm gate, if the exempt sales are to bear some VAT. Getting rid of the unrelieved VAT on inputs in the agricultural sector is particularly relevant at the export stage.

Under the exemption regime, regardless of the threshold, in principle no farmer would have to register for VAT purposes and all farmers would be assumed to be able to pass the VAT on their inputs through to agro-processing firms. Again optional registration would and generally should be made available, but this would increase compliance costs, particularly for small farmers. Agricultural processing firms, which would generally be large, would be registered. They would not be able to take a deduction for the VAT incurred by nonregistered farmers on their inputs. Hence, this tax would cascade throughout the production-distribution process and would likely result in a higher VAT burden at the consumer level than if farmers and processing firms had been subject to a full taxation regime. Obviously, sales at the farm gate would not be subject to the tax-on-tax effect.

Input VAT relief can be made available to farmers under the taxation regime if their turnover falls below the threshold and they do not elect to register. With full input VAT relief, the right of optional registration would not have to be exercised and the 
attendant compliance costs would not have to be incurred. Similarly, input VAT relief can be made available to any farmer under the exemption regime who does not elect to be registered.

Input VAT relief can take one of the following four forms:

- Specified inputs sold to farmers are exempted. This form of relief tends to be ill designed since farmers would still be stuck with the input VAT of suppliers. Also, the relief is ill targeted if users other than farmers would benefit from the exemption or be burdened by the unrelieved VAT on inputs of the exempt products if they are not registered for VAT. This can be prevented by so-called end-use exemptions-that is, inputs would only be exempted if sold to farmers. However, end-use exemptionsredundant in the case of taxable farmers-are notoriously difficult to monitor. ${ }^{16}$

- Specified inputs, such as seed, feed, fertilizers, insecticides and perhaps other inputs, such as agricultural machinery, can be taxed at a reduced rate or be zero rated ${ }^{17}$ so that exempt farmers incur less or no VAT on their inputs of these goods and, hence, there is less or no hidden tax in the price of their output. The problem with this approach is that dual-use goods, such as building materials and means of transportation, which can be used for business as well as private purposes, in as well as outside the agricultural sector, should not be zero rated if revenue leakage is to be prevented. Accordingly, it is advisable to confine the reduced or zero rate to goods and services that can only be used for agricultural purposes. ${ }^{18}$

- Agricultural inputs are taxed, but farmers are compensated for the VAT included in the price of these inputs through a flat-rate scheme - that is, they charge a presumptive VAT on their sales to agro-processing firms (which would be able to take a deduction for this VAT), but would not have to register and file returns themselves and would be able to keep the VAT on sales as compensation for the VAT on purchases. Alternatively, but equivalently, farmers would not charge VAT on their sales but agro-processing firms would still be able to credit the presumptive VAT on farmers' inputs and presumably pass the benefit back to farmers. Importantly, the flat rate should approximate the average tax on inputs. Flat-rate schemes are a unique European phenomenon. ${ }^{19}$

- The VAT on specified inputs, collected from suppliers by the government, can be paid out to farmers proportionate to their purchases of these inputs. Farmers would either have to file refund claims for the input VAT or the average payouts would be calculated in the same way as the rate under the flat-rate scheme. This form of input VAT relief is not found in many countries.

16 In practice, various Latin American and African countries exempt principal agricultural inputs from VAT. See Tait (1988, chapter 7) and Cnossen (2015).

17 Zero rating has been recommended by Tait (1988) and by Due (1990).

18 Outside the EU, a large number of African countries apply a zero rate to agricultural inputs (Cnossen 2015).

19 Note that the presumptive agricultural flat-rate scheme is different from the equally presumptive flatrate schemes used to tax small traders. While the latter schemes are meant to extract some tax from small traders (in lieu of VAT on their value added, which is difficult to ascertain), agricultural flat-rate schemes are meant to compensate exempt farmers for the VAT incurred on inputs, which they cannot recoup otherwise. Presumably, the two presumptive approaches are also different in the direction in which VAT policy designers would wish to err. 
Output VAT relief means that (un)processed farm products sold to consumers are exempted, zero rated or taxed at a positive but lower-than-standard rate. Of course, the benefit of this form of relief accrues primarily to consumers, but some of the benefit may be passed back to farmers, depending on demand and supply elasticities. This form of relief is found in many countries, although newcomers to the VAT have tended to stay away from output relief. The pros and cons are discussed in Sect. 6.

\section{Taxation regime}

Table 2 shows the VAT taxation regimes in 10 EU Member States and 12 (other) OECD countries. For each country, the table lists the standard rate, reduced rate(s) on agricultural inputs (especially fertilizers and pesticides), the treatment of foodstuffs and the threshold. ${ }^{20}$ These 22 countries, about half of the 40 countries under review in this article, treat the agricultural sector the same as any other sector for VAT purposes. ${ }^{21}$ Output above the threshold is taxed and a credit is permitted for the VAT on inputs. Accordingly, these countries believe that optional registration is sufficient to enable farmers to pass on the VAT on inputs if they want to do so. Thirteen out of the 22 countries with a taxation regime tax inputs at the standard rate. Only six countries go all out in treating the food sector as any other sector by taxing all foodstuffs at the standard rate.

In all but four of these countries, environmentally unfriendly inputs, such as chemical fertilizers and pesticides (as well as fuels), are taxed at the standard rate. Exceptionally, Canada, Korea, Romania and Switzerland apply lower rates, which should be helpful in reducing the VAT burden on exempt farmers. But it should be noted that while fuels are subject to externality-correcting excise taxes in nearly all of these countries, only the Nordic countries subject pesticides and Denmark and Sweden fertilizers, too, to an excise tax on account of the external costs (air and water degradation) that these products bring in their train (UNDP 2017). Eight countries levy reduced rates on various inputs, such as feed, seed, machinery and equipment. Korea and Mexico apply a zero rate to sales of farm machinery and equipment. Applying the full VAT should have some effect in reducing the use that is made of them by exempt farmers.

Thirteen out of the 22 countries with a taxation regime for agriculture apply a reduced rate to foodstuffs in general. In five of these countries-Australia, Canada, Korea, Malta and Mexico - that rate is zero. In four countries, the reduced rate does not apply to restaurants, which, presumably, induces restaurant owners to categorize some on-premise sales as off-premise sales. Croatia and the Czech Republic continue

\footnotetext{
20 Obviously, the reduced or zero rate on inputs does not help taxable farmers (because the subsequent tax credit of the processor will be smaller), but it does help exempt farmers who do not elect to register and would not have to incur compliance costs in doing so.

21 Japan's farmers fall under the regime for small and medium-sized enterprises. Accordingly, small-scale farmers whose taxable sales are not more than JPY 10 million $(€ 87,930)$ are exempt from the requirement to register for consumption tax, but can register voluntarily. Further, farmers whose annual taxable sales amount is no more than JPY 50 million $(€ 439,650)$ can use the 'simplified taxation scheme'. In their case, a deemed tax credit is available calculated as a percentage of the VAT on sales. Depending on trade or industry, the tax credit ranges between 50 and $90 \%$ of the VAT on sales. Finally, the VAT on any equipment purchased by farmers or fishers is refundable, while purchases of petroleum products are exempt from VAT. See Weichenrieder (2007).
} 


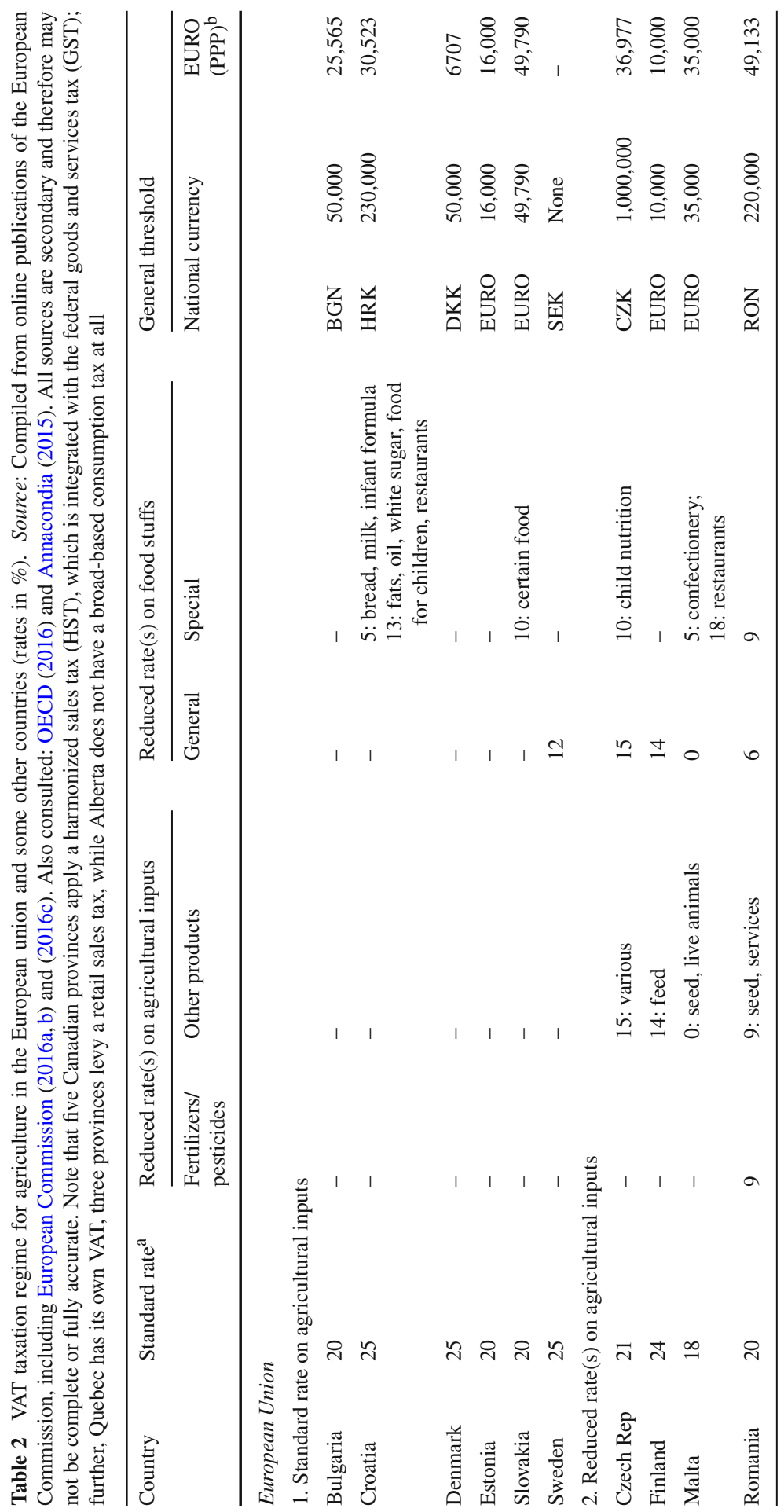




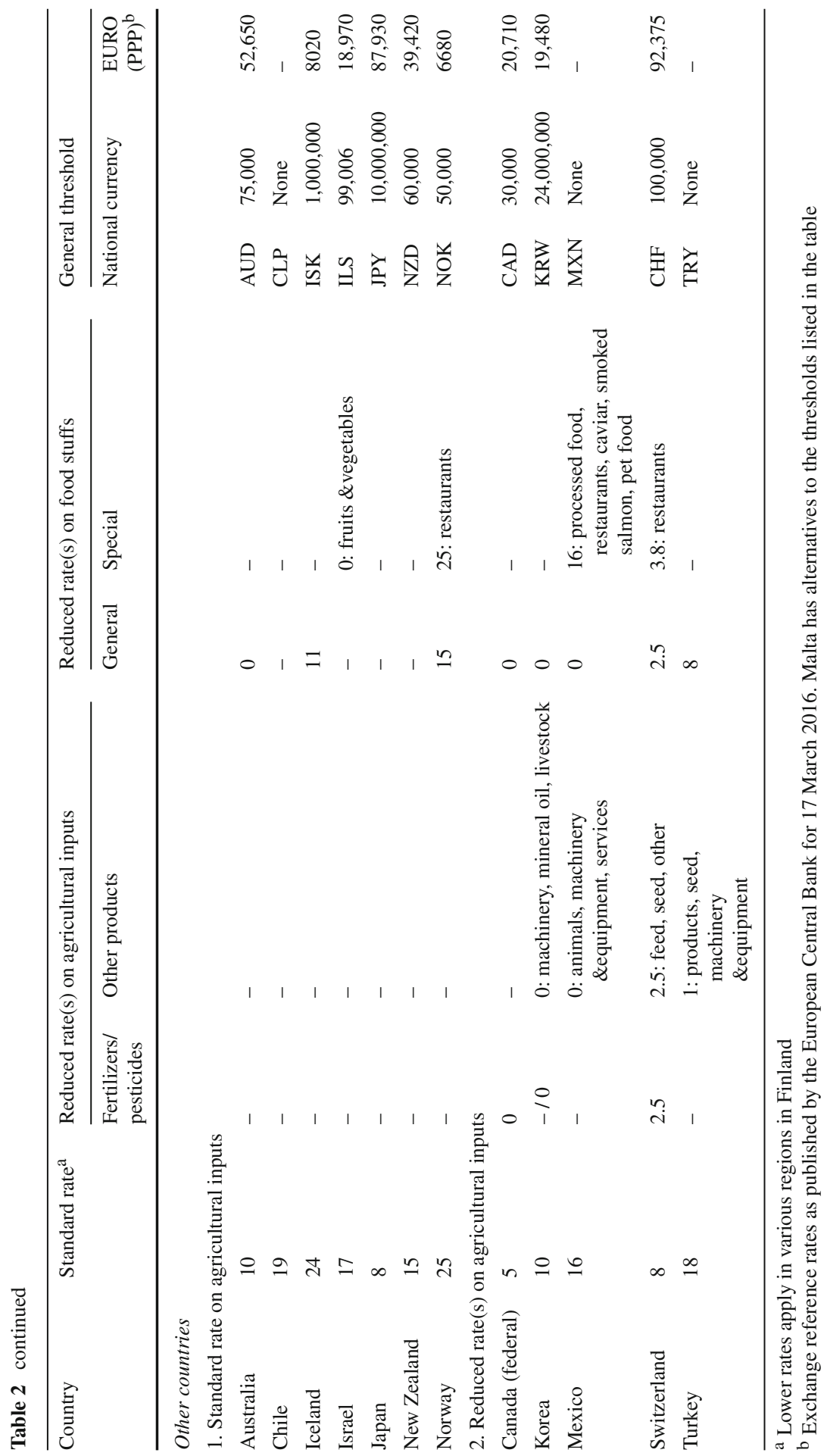


the old Soviet tradition of taxing child nutrition at a reduced rate. The pros and cons of a reduced rate on foodstuffs, which is also prevalent under flat-rate schemes, are discussed in Sect. 7.

Finally, the threshold varies widely among all 22 countries, ranging from no threshold in Chile, Mexico, Sweden and Turkey to the equivalent of $€ 92,375$ in Switzerland. In monetary terms, particularly Nordic countries-Denmark, Finland, Iceland and Norway-have rather low thresholds, while Sweden has no threshold at all. Apparently, the incremental costs of collecting the VAT and complying with it are so low in these countries that even very small traders can be kept in the VAT's ambit. Costs are kept low by administering the VAT in conjunction with the income tax, often using the same return on a year-end reconciliation basis. To illustrate, in Norway, persons engaged in agriculture and forestry submit annual returns within a period of 3 months and 10 days after the expiration of the calendar year. In turn, these returns form the basis for presumptive quarterly VAT payments in the following year. ${ }^{22}$ Presumably, this is possible because the income tax in Norway (and other Nordic countries) reaches deep down in the income distribution which is not done or not possible in other countries.

Generally, the size of the threshold is not related to the level of the VAT rate on agricultural inputs, although it might be expected that a lower threshold would imply a standard VAT rate on inputs, because there is less need for VAT relief.

\section{Exemption regime or flat-rate scheme}

The flat-rate scheme is the most widely-used form of providing relief for the VAT on inputs used by exempt farmers in the EU.

\subsection{Details of the flat-rate scheme}

The particulars of the flat-rate scheme, which can be found in Chapter 2 of Title XII of the Common VAT Directive (2016), are the following:

- The scheme applies to the activities of an 'agricultural, forestry or fisheries undertaking' as defined in Annex VII of the Directive and to 'agricultural services' as defined in Annex VIII (Box 2); they connote a wide definition of agriculture, forestry and fishing. Also included are processing activities of products deriving essentially from the farmer's own production.

- The compensation for exempt farmers of the VAT on their inputs is provided in the form of a fixed percentage of the farmers' output net of VAT, differentiated, if desired, by the kind of activity, be it agriculture, forestry or fisheries.

- In practice, farmers who want to join the scheme must notify the VAT authorities. Alternatively, the purchaser of the farm produce should do so.

\footnotetext{
22 Persons engaged in agriculture may include supplies not coming from their agricultural activities in their annual returns as long as these supplies do not exceed NOK 50,000 (€5500). This type of provision is also found in many other countries.
} 
Box 2 European Union: definition of agricultural production activities and services for VAT purposes. Source: Article 295 and Annexes VII and VIII of the Common VAT Directive (2006)

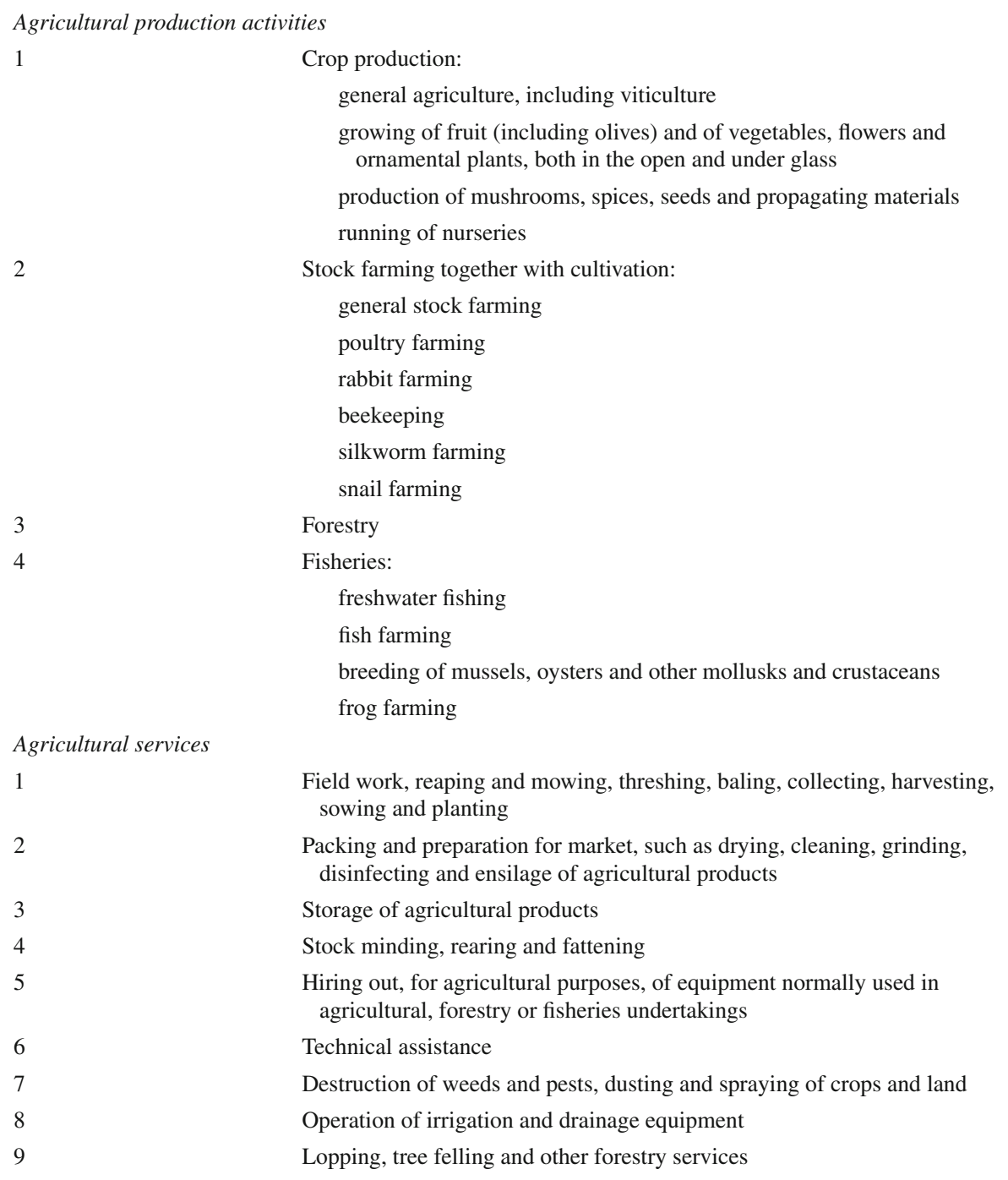

- The flat-rate compensation percentage is calculated on the basis of national accounts statistics for the agricultural sector of the preceding three years, derived from sectoral input-output tables showing, inter alia, the inputs that have been subject to VAT.

- The flat-rate addition is not VAT but acts as compensation for losing input VAT on purchases. It is not intended as reimbursement for all the VAT incurred on purchases and cannot provide greater relief for farmers than the VAT charged on their inputs. 
- The flat-rate addition is added to sales by exempt farmers (or to purchases by the processor), except in the case of the sales of machinery and land and the repair and maintenance of farm buildings. The flat rate cannot be charged on sales to people not registered for VAT or on sales to other flat-rate farmers.

- Flat-rate farmers must issue invoices, so taxable purchasers of farm produce can take a deduction for the amount of the flat rate. Alternatively, purchasers of the products of flat-rate farmers should issue invoices to flat-rate farmers, which the latter should keep as proof for tax audit purposes.

- The compensation can be provided in the form of a refund by the government to farmers of their input VAT or in the form of a payment from purchasers of their output to whom farmers would have charged the flat rate on their output.

- Exempt farmers have the option of VAT registration and payment, but then they are not entitled to the benefits of the flat-rate scheme.

- Flat-rate farmers who export their products are entitled to a refund of the flatrate compensation amount. Similarly, importers from EU countries with flat-rate schemes can apply for a refund of the compensation amount from the exporting Member State.

- The flat-rate percentages calculated by the Member States have to be notified to the European Commission, which monitors the percentages to see whether the scheme is used to provide hidden subsidies to agriculture, which are not allowed.

To summarize, the objective of the flat-rate scheme is simplification (no VAT registration for farmers) and neutrality (permitting compensation for the input VAT). Of course, this involves a trade-off. Complete simplification (no VAT at all) and full neutrality (exact compensation) is not possible. On this trade-off, the European Court of Justice (2012) opined:

It is true that the result of paying simple compensation which is entirely flat-rate does not, by definition, ensure the complete neutrality of VAT. It does however achieve the highest neutrality possible taking into account the need to reconcile that payment and the objective of compensation with the objective of simplification of the rules to which flat-rate farmers are subject, which is also one of the objectives of the flat-rate scheme for farmers ...

Clearly, in view of the lawmaker's earlier preference for flat-rate treatment, the Court cannot recommend an alternative scheme that would go even further in reconciling simplification and neutrality. So, it has to run with the hare and hunt with the hounds. $^{23}$

\subsection{Practical application}

As shown in Table 3, the flat-rate scheme has been adopted by 18 countries, all EU Member States. States with a flat-rate scheme either exempt the whole agricultural

\footnotetext{
23 For a useful analysis of jurisprudence on the flat-rate schemes for farmers with particular reference to Germany, see Beugel (2016).
} 
sector (subject to optional registration) or apply the flat-rate scheme only to farmers whose turnover is less than a prescribed threshold (Austria, Belgium, Greece, Spain and the UK) or whose farm is smaller than a prescribed size (Lithuania). France, Germany and Italy differentiate the compensation rates by reference to the type of product produced. Belgium, Germany, Italy, Luxembourg and Spain differentiate the compensation depending on the type of activity, be it agriculture, forestry or fisheries.

In addition to the flat-rate scheme, all but two Member States tax agricultural inputs at reduced rates. ${ }^{24}$ Doing so should lower the scheme's compensation rate, because there is less input VAT to be relieved. But this is not obvious from the table when the flat-rate compensation rates are compared with the lower rate on inputs. Austria, Germany, Luxembourg and Spain have high compensation rates, but also apply reduced rates to inputs. Presumably, the reduced rates on agricultural inputs, such as tires and tubes (Belgium), machinery (Portugal) and fuel (Portugal, the UK) cause delineation problems in administering the VAT. Noteworthy is the monetary compensation that France provides to very small exempt farmers for the VAT they are assumed to have paid on their inputs. The compensation is calculated in the same way as the amount under the flat-rate scheme. Larger exempt farmers are subject to the flat-rate scheme.

As shown in Box 3, the flat-rate scheme takes on grotesque forms in France and particularly Italy. It must be difficult in France to explain the precision with which the flat rate is calculated: $5.59 \%$ for some agricultural products and $4.43 \%$ for various other products. Much more problematic are the 11 flat rates in Italy. Who can explain the difference between $7.65 \%$ (two decimals!) compensation for live animals of bovine species and $7.95 \%$ (two decimals!) for pork species, or the $8.3 \%$ compensation for certain types of meat and $8.5 \%$ for other types of meat and fat. This is a way to keep clerks busy and shift the focus away from basic compliance control.

The treatment of intra-EU transactions by flat-rate farmers, although not mentioned in the table, is also dealt with in the Common VAT Directive (2006). If exempt farmers sell their output to a taxable person in another Member State, the receiver of the output can claim a refund of the flat-rate amount from the VAT administration of the supplier's Member State. In case of distance sales, the flat-rate farmer would be taxable in the Member State of arrival if his sales exceed the threshold prescribed for these sales; if not, he can ask for a refund from his own VAT office. Recipient flat-rate farmers are taxable on supplies from other Member States in the state of purchase. Clearly, these are complicated obligations to comply with.

The flat-rate scheme states tend to tax foodstuffs at a reduced rate, except Lithuania, which is a newcomer to the common VAT in the EU and has taken to heart the lessons from the less-than-encouraging experience with lower rates in other countries. The pros and cons of taxing foodstuffs at reduced rates are discussed in Sect. 7. Here it should be noted that 9 out of 18 states with a general reduced rate on foodstuffs tax on-premise consumption (restaurants) at a higher rate than off-premise consumption. There is firm evidence for Germany that this practice stimulates tax evasion by labeling on-premise consumption as off-premise consumption. If foodstuffs should be taxed at

24 Belgium, France, Italy and the Netherlands impose an excise on pesticides (UNDP 2017), but no flat-rate country levies an excise on chemical fertilizers. 


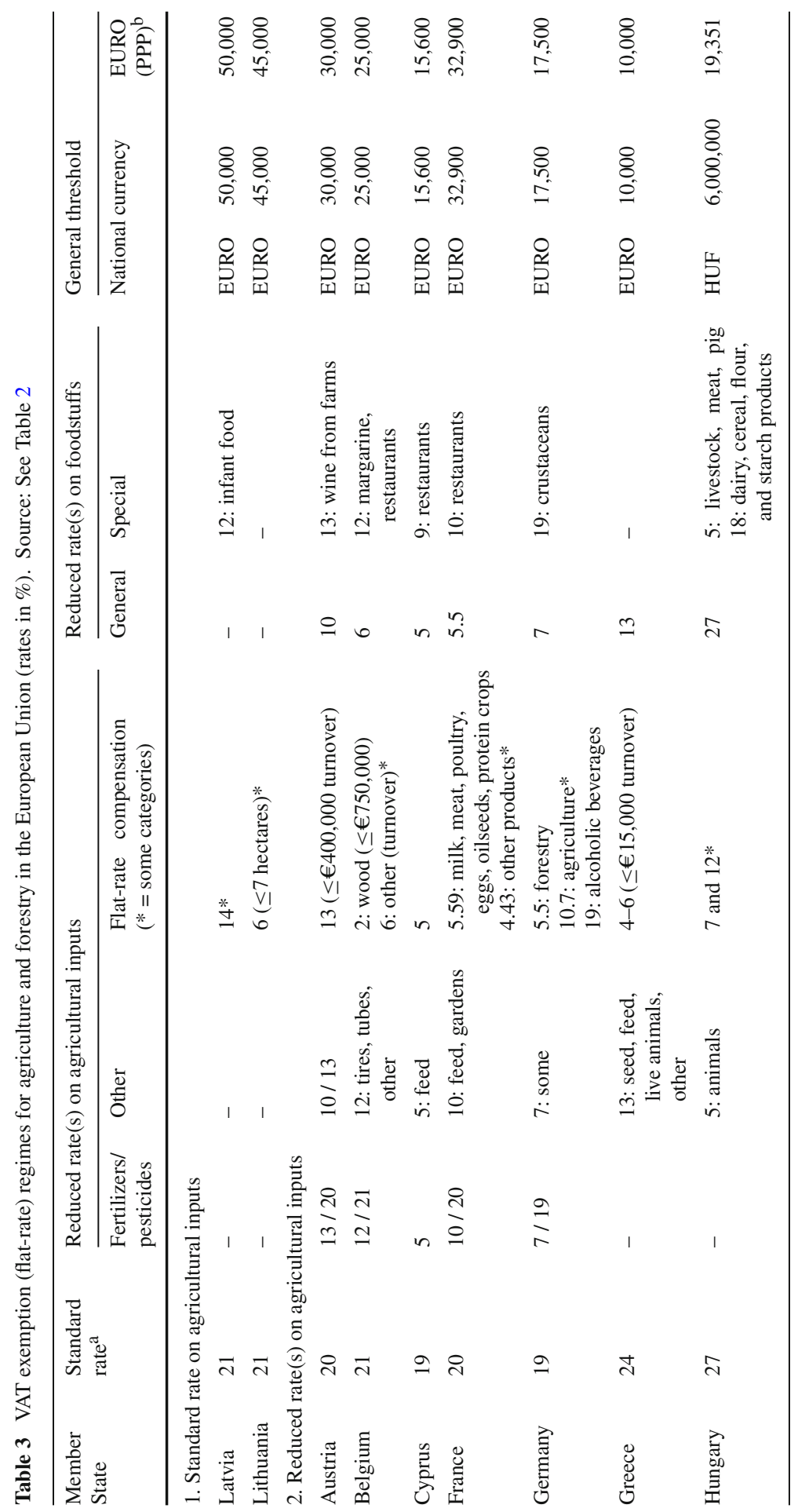




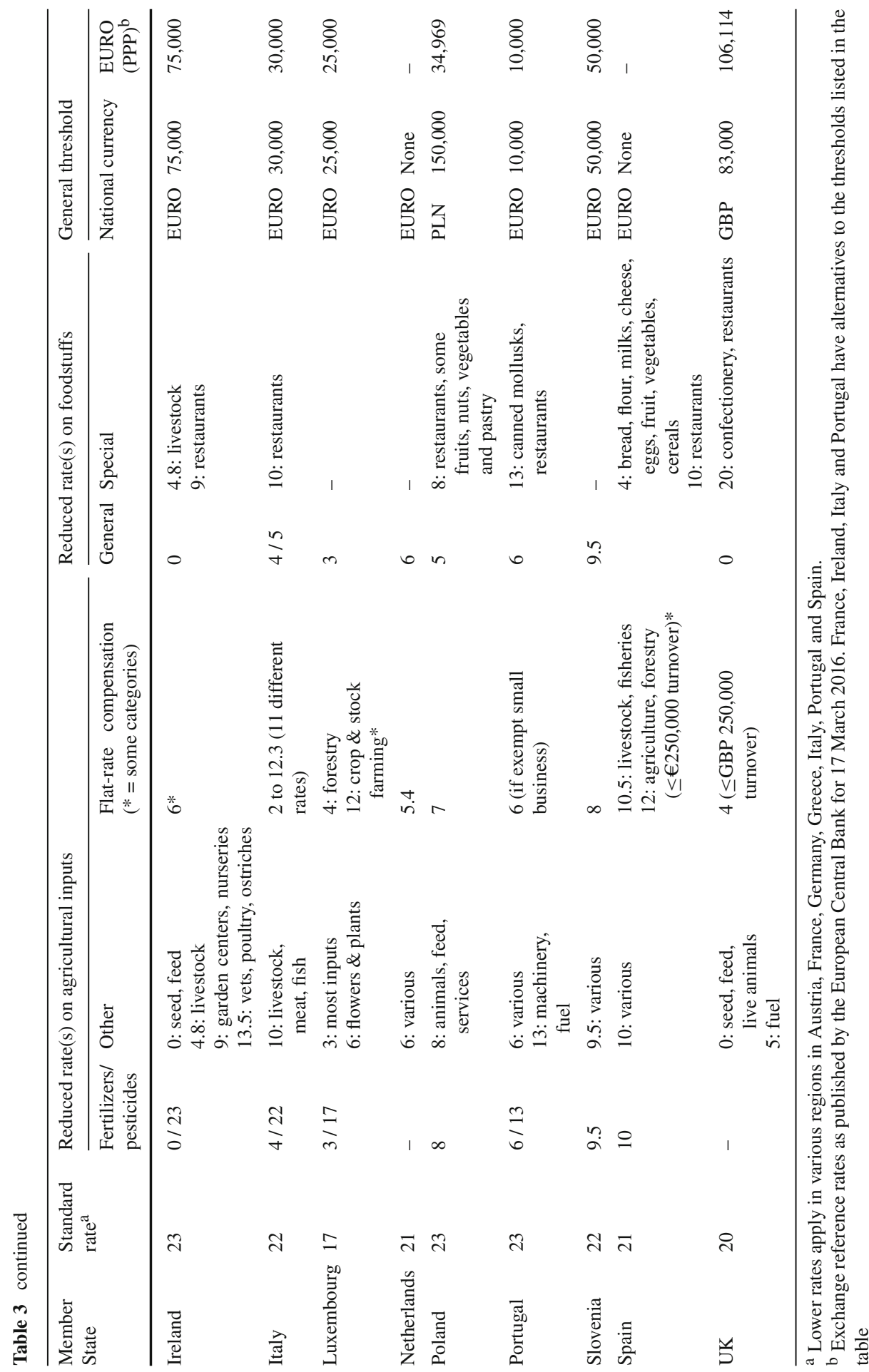


Box 3 France and Italy: VAT flat-rate compensation percentages. Source: European Commission, 2016b

\begin{tabular}{|c|c|c|}
\hline Country & Flat-rate percentage & Products \\
\hline \multirow[t]{2}{*}{ France } & 5.59 & $\begin{array}{l}\text { Milk, poultry and rabbits, eggs, meat and charcuterie } \\
\text { animals, oilseeds, protein crops }\end{array}$ \\
\hline & 4.43 & Other products \\
\hline \multirow[t]{11}{*}{ Italy } & 2 & Wood, natural cork \\
\hline & 4 & $\begin{array}{l}\text { Frogs, fish, crustacean and shellfish, fresh milk for food } \\
\text { consumption, packaged for retail and milk products, } \\
\text { plants and parts of plants, vegetables and eatable } \\
\text { plants, fruit, spices, cereals, algae, oil of olive, cider, } \\
\text { wine, vinegar, raw tobacco and raw flax }\end{array}$ \\
\hline & 7.3 & $\begin{array}{l}\text { Horses, sheep, goat, certain other domestic animals such } \\
\text { as rabbits and pigeons, bees and silkworms }\end{array}$ \\
\hline & 7.5 & Poultry \\
\hline & 7.65 & Live animals of bovine species \\
\hline & 7.95 & Live animals of pork species \\
\hline & 8.3 & Certain types of meat \\
\hline & 8.5 & Certain types of meat and fat \\
\hline & 8.8 & Eggs, honey, wax, fur \\
\hline & 10 & Fresh milk not treated for retail sale \\
\hline & 12.3 & Wines of fresh grapes with some exclusions \\
\hline
\end{tabular}

a reduced rate, best practice would be to tax all foodstuffs sold on or off premise at that rate, even though this increases the overall regressivity of the VAT. This is what Greece, Luxembourg, the Netherlands, Romania and Slovenia do.

Again, the size of the threshold does not appear to be related to the type of VAT relief for farmers, although a flat-rate scheme is more likely in countries, such as the UK, that have a high VAT threshold, because the number of farmers that are stuck with unrelieved input VAT tends to be larger.

\section{Evaluation of input VAT relief schemes}

By design, the flat-rate scheme is a rather arbitrary way to compensate exempt farmers for the VAT on inputs. Possibly, zero rating selected farm inputs would be a bettertargeted alternative. But regular taxation appears to be the best approach.

\subsection{Problems with the flat-rate scheme}

As already noted by Tait (1988, pp. 144-145), the flat-rate scheme brings a number of problems in its train, which deserve to be reviewed.

First, farmers with a relatively high amount of VAT on inputs will be undercompensated (in a sense, taxed), while farmers with a relatively low amount of VAT on inputs will be overcompensated (in a sense, subsidized), which appears at odds with 
basic notions about equal treatment as well as with the EU's competition policy. ${ }^{25}$ Undercompensated farmers can register and pay VAT, but this means that they incur compliance costs, which they have to balance against the extra relief. And this still does not justify the fact that other farmers are overcompensated. It is to be expected that, generally, the flat-rate scheme tends to overcompensate farmers (Terra and Kajus 2015, p. 5072).

Secondly, Table 3 shows that flat-rate compensation is anything but harmonized across the EU. Some schemes are applied sector-wide, other schemes are subject to turnover limits, yet other approaches go by the type of farm product. In turn, these different schemes interact with the various reduced rates that are applied to farm inputs, resulting in a nontransparent tableau of compensation rates. It is unlikely that equal treatment within or between Member States will be achieved. Further down the production-distribution chain, this should affect the effective VAT rate on foodstuffs.

Allegedly, the intra-EU differences in the schemes can be used to indirectly subsidize farmers. To illustrate, in the spring of 2016, the French pork industry lodged a complaint with the European Commission, accusing German farmers of VAT fraud worth $€ 250$ million since 2008 (EurActiv 2016). German farmers are allowed to use a flat-rate VAT scheme that permits them to charge a flat-rate addition per animal. In France, this scheme is only applicable to businesses with turnover of less than $€ 76,000$, but since French pork producers do not have such low turnovers, the whole sector finds itself at a disadvantage to its German counterpart. German producers reap a benefit of more than $€ 1$ per pig from this scheme by cutting VAT from 10.7 to $9.4 \%$, according to the anti-fiscal-dumping group of the French pork industry. ${ }^{26}$

Thirdly, the flat-rate scheme brings its own complexities in train. If flat-rate farmers also carry on other activities, say B\&B operations, then the turnover of these activities has to be separated from the farming activities and taxed under normal arrangements if the turnover exceeds the threshold. This involves the usual contentious input VAT allocation problems well known from the general exemptions relating to finance, insurance, health care and education. Other administrative complications arise regarding the export of agricultural produce by exempt farmers, particularly if a refund claim has to be lodged by the recipient of the goods in the receiving Member State with the VAT administration of the supplier's Member State.

Further, in practice, it is not always clear which inputs are eligible for inclusion in the compensation scheme. Obviously, goods and services that have no alternative use outside the agricultural sector should be included but, as Fig. 1 indicates, there are various dual-purpose goods whose use for farming purposes must be difficult to separate from private use, including maintenance costs for farm buildings (including dwellings?) and transportation costs. Expenditure on these items can differ widely between farmers. The Irish solution is to allow farmers to file refund claims for the

\footnotetext{
25 Tait (1988) cites an early Spanish study by García Azcárate (1986), who shows that the compensation could vary from $1.1 \%$ for olives to $5.7 \%$ for intensive market gardening, as well as by region from $2.9 \%$ in Andalucía to $4.7 \%$ in other regions. As Tait (1988, p. 144) notes, 'A flat rate VAT allowance of $4 \%$ (now $12 \%$ !) clearly only achieves rough justice'.

26 Gérard Viel, the president of the French livestock and meat Coop, has called this a form of aggressive tax planning rather than a way to free small businesses from the obligation to set up complicated accounts. The case is still under review.
} 
input VAT on machinery, buildings and means of transport, but this approach is not followed by most other Member States. ${ }^{27}$

The flat-rate scheme may also be an invitation for farmers and processing firms to collude in defrauding the VAT collection agency by artificially increasing farmers' selling prices. By the same token, direct monetary compensation by the government involves a form of bureaucratic discretion that can be abused.

Fourthly, the flat-rate scheme may work at cross purposes with the VAT rules on the EU's own resources, ${ }^{28}$ as two examples illustrate. In 2008, Portugal introduced an optional exemption for agricultural activities, exempting VAT on supplies provided by farmers unless they opted to apply the normal VAT arrangements. In addition, the flatrate compensation percentage was fixed at a zero rate: farmers were not compensated for the VAT paid on their inputs, which was calculated at 5-12\%. The European Commission (Opinion 2008/2082) opined that since too much VAT was levied from the sector, Portugal made a substantial negative compensation in its own resources to compensate for this factor. In the subsequent legal proceedings, the European Court of Justice (2012) steered away from the own-resources issue and argued that the objective of simplification cannot justify the introduction of an exemption that is not provided for by the Common VAT Directive. Accordingly, Portugal had to modify its flat-rate scheme.

A similar event happened with regard to Germany, which in 1984 wanted to use the flat-rate scheme to compensate its exempt farmers for the losses they suffered from the revaluation of the currency (Tait 1988, p. 145). This special compensation was an addition of $3 \%$-points to the flat rate. This move was disputed by the European Commission, which argued that (a) its own resources suffered because Germany collected less VAT and (b) the compensation discriminated against farmers in other Member States. In the end, Germany got away with the increase in the flat rate, but had to correct its own-resources account.

Finally, it should be pointed out that 10 EU Member States do not have a flat-rate scheme, but deal with farmers under normal VAT arrangements. These states range from middle-income countries (Bulgaria, Romania) to upper-middle-income countries (Czech Republic, Croatia, Estonia, Slovakia, Malta) to high-income countries (Denmark, Finland, Sweden). Apparently, countries at very different levels of development can handle the normal arrangements. And, not to forget, the flat-rate compensation arrangement is not found in non-EU countries.

More generally, the flat-rate form of compensation appears to be out of date in view of the ongoing enlargement and mechanization of agricultural activities in the EU requiring full and unrestricted compensation for the VAT on capital goods and other inputs. Not surprisingly, in the Netherlands, 'old' farmers tend to be in the flatrate scheme, while 'young' farmers have opted for the regular regime. Early on, the European Commission was already of the opinion that the flat-rate scheme should

\footnotetext{
27 Tait (1988, p. 144) writes that the proceeds of sales of capital goods by farmers may be exempted or included in the basis for calculating the flat-rate compensation.

28 The EU's budget is financed by its own resources, which consist of the proceeds from customs duties on imports from outside the EU and sugar levies collected by the Member States, a specified percentage of the harmonized VAT base in each state, and a uniform percentage of each state's gross national income.
} 
be confined to small farmers - the ceiling being established by reference to criteria relating to turnover or quantities produced per hectare (Tait 1988, p. 144). Perhaps, the flat-rate scheme has become redundant after the CAP reform, which provides for income support measures.

\subsection{Would zero rating major inputs be a better alternative?}

If relief for the VAT on inputs should be provided other than through a flat-rate scheme, a feasible alternative would seem to be to zero rate various major inputs, such as feed, seed, chemical fertilizers, pesticides and perhaps agricultural machinery-in short, inputs that do not or hardly have alternative uses. The following arguments can be forwarded in support of this solution:

- In contrast to the flat-rate scheme, the zero rating of major inputs is relatively easy to administer. Generally, the zero-rated inputs would be sold by large manufacturing or trading units with good accounts and capable of accounting for VAT refund claims. Obviously, zero rating would not involve the farmers themselves in issuing invoices or keeping accounts. Also, farmers would not have to show a certificate to suppliers that they are genuine agriculturalists, which they have to do in Ireland, for instance, in order to be able to buy zero-rated inputs.

- Zero rating would involve a current benefit, whereas under the flat-rate scheme the time that elapses between the date of purchase of the inputs and the date the invoice is issued for the output, and compensation would become available, would imply that farmers would incur an interest cost on the VAT that is to be compensated. This cost can be high in times of high inflation.

- The same argument applies if processing firms pay farmers for their output and the VAT attributable thereto some time after farmers have invoiced the presumptive VAT on inputs. Again, the farmer would incur an onerous interest cost.

- In contrast to the flat-rate scheme, zero rating would also work if exempt livestock farmers buy, say, grain or corn from exempt crop farmers, since the latter would not have paid VAT on inputs either.

While zero rating is by far the simplest form of VAT relief from the exempt farmer's perspective, nevertheless a few 'ifs' should be kept in mind.

- The zero rate should be confined to agricultural inputs that have no alternative use outside the agricultural sector, not to, say, building materials and means of transportation. If desired, a VAT refund scheme could be applied to VAT incurred in relation to the construction, extension, alteration or reconstruction of farm buildings and structures and on land drainage and land reclamation. Obviously, expenditures on these items are less evenly distributed among farmers and hence less susceptible to a flat-rate scheme, while zero rating would be difficult to administer in view of the dual-use nature of these items.

- Further, the government should not justify the VAT as a proxy for the environmental tax that should be levied on chemical fertilizers and pesticides. Although the environmental harm of using these products should be accounted for in price, the appropriate instrument would be a specific excise rather than an ad valorem VAT. 
The specific excise can be directly linked to the environmental damage, while there is no relationship between the value of a product and the damage that it inflicts. This excise should apply to imported as well as domestically produced chemical fertilizers and pesticides.

- Lastly, there is no reason why very small farmers farming for their own consumption and for the local market should also benefit from the zero rate on agricultural inputs. Instead, the unrelieved VAT can be viewed as a tax on their own consumption and on the consumption of customers not paying taxes either. This can be achieved by stipulating that the zero rate applies only if the zero-rated inputs are sold by manufacturers or wholesalers directly to farmers in quantities of at least, say, 10 kilograms, as is the case in Ireland. But this means that farmers would have to show a certificate to suppliers stating that they are genuine farmers, a rather awkward administrative complication.

\subsection{Preferred choice}

While the flat-rate scheme is an arbitrary way to relieve exempt farmers from the VAT on inputs, the zero rating of selected major inputs violates the integrity of the VAT. Not surprisingly, originally, the European Commission wanted to phase out the flat-rate scheme (Terra and Kajus 2015, pp. 5071-5072) and subject farmers to the normal regime or the special scheme for small enterprises. This review suggests that first-best VAT practice is to treat the agricultural sector the same as any other sector, as is done under the VATs in Denmark and New Zealand, for instance, countries that have relatively large agricultural sectors. Farmers are not really different from other businesses. They can register for VAT purposes and pass the tax on inputs on to agro-processing firms if they want to get credit for the VAT. Most farmers have much better accounts than in the 1960s when the EU VAT was introduced. Farmers who sell at the farm gate can choose to remain exempt, a status that would be beneficial to them.

In this philosophy, the reduced rate on agricultural inputs, which many countries have, should be abolished. The reduced rate can only be applied to inputs that have no alternative use outside the agricultural sector. Building materials or tractors should not be taxed at lower rates if revenue leakage is to be prevented. Another issue is that pesticides and chemical fertilizers are environmentally unfriendly products whose external costs should be internalized in price. Ideally, they should be subject to a nondeductible and nonrefundable excise tax. In the absence of such an excise, there is an argument for levying the full VAT on these inputs. ${ }^{29}$ In short, reduced rates have no place under a full taxation regime. Further, it does not seem unreasonable that household farmers basically producing for their own consumption and for the local market pay some tax on the inputs to their foodstuffs. A final consideration is that the VAT should be applied regardless of the other interventionist policy instruments that

29 This argument is made in Ebrill et al. (2001, chapter 9). 
the EU Commission has available. The VAT should not be modified in the pursuit of these objectives.

\section{Should foodstuffs be taxed at a reduced VAT rate?}

In most EU Member States but in many other countries too, foodstuffs tend to be taxed at reduced VAT rates (see Tables 2, 3). By contrast, the theoretical literature shows that the application of a uniform rate is optimal, although this result is subject to rather stringent conditions. The practical arguments in favor of a uniform rate are so strong, however, that this is usually regarded as 'best practice' (Keen 2013). The treatment of foodstuffs affects farmers and therefore deserves to be discussed here. ${ }^{30}$

\subsection{Misallocation of resources}

Taxing foodstuffs at reduced rates changes relative prices, leading consumers to buy relatively more foodstuffs and producers, including farmers, to choose food production over other lines of production. The effect on quantities demanded will induce intersectoral movements of the factors of production and result in changes in factor prices. Resources will be directed from their most profitable use to less profitable uses. In the end, total output will be less than it would be with a single rate. Given the amount of revenue to be raised, it also means that the standard rate must be higher, which should magnify the distortion of consumer preferences and producer choices. This effect deserves some attention, because, as a rule, the severity of tax distortions increases with the square of the tax rate that causes them. ${ }^{31}$ In short, everyone will be better off with a uniform standard rate, provided that all households are compensated for the loss in income (Crawford et al. 2010).

The Institute for Fiscal Studies (2011) quantifies the potential welfare gain from rate unification for the UK and discusses the gain for Belgium. An increase in the reduced rates (including the zero rate on food and dwellings in the UK) to the level of the standard rate implies a welfare gain of $3.5 \%$ of total VAT receipts in the UK. The welfare gain for Belgium is even greater, at $4.6 \%$. In an alternative scenario, the elimination of the reduced rate is combined with a reduction of the standard rate by 5\%-points for the UK and 3\%-points for Belgium, so that VAT yields stay the same. This results in a welfare gain per household of $€ 0.95$ per week in the $\mathrm{UK}^{32}$ and

\footnotetext{
30 Much of the following draws on Bettendorf and Cnossen (2015).

31 For the classic analysis, see Harberger (1964). The argument in favor of a uniform VAT rate is at odds, of course, with the famous 'Ramsey rule' of taxation, which holds that the efficiency cost of taxation can be minimized by taxing price-elastic goods (such as caviar) at a low rate and price-inelastic goods (bread, for instance) at a high rate. As Harberger (1990) has argued persuasively, however, uniform taxation can be defended on pragmatic policy grounds. Unlike the Ramsey-rule solution, it does not require knowledge of demand and supply relations (generally not available anyway) and is more robust to changes in tastes and technology.

32 This is the mean of the numbers in table 9.17 in Institute for Fiscal Studies (2011), but on p. 421 the number is $€ 1.07$.
} 
$€ 0.74$ per week in Belgium. These gains are small, but it is through small gains that high-income countries may wish to raise their standards of living.

\subsection{Reducing regressivity}

Usually, reduced VAT rates on foodstuffs are rationalized by the argument that essential goods and services are disproportionately consumed by the poor. ${ }^{33}$ Recently, the OECD / Korea Institute of Public Finance (2014) have examined this argument by using microsimulation models for 20 member countries. Assuming that households do not alter their consumption patterns in response to an increase in reduced VAT rates, ${ }^{34}$ the study finds that most, if not all, of the reduced rates that are introduced for the distinct purpose of supporting the poor-such as reduced rates on food, water supply and energy products - do have the desired progressive effect. Nonetheless, reduced rates are shown to be a very poor tool for targeting support to poor households. ${ }^{35}$

Further, in the case of an individual country, the Netherlands, Bettendorf and Cnossen (2015) evaluate the effectiveness of reduced VAT rates at redistributing income toward poor households on the basis of the spending patterns of individual households over various income deciles in the Netherlands as reported in a 2004 household budget survey. After adjusting incomes and expenditures for the size and composition of households, they express differences in VAT burdens between lowerand higher-income groups through what is called the effective VAT rate-that is, total VAT payments of a normalized household as a percentage of disposable income (excluding income tax and VAT). As shown in the left panel of Fig. 2, the VAT burden drops slightly from decile 3 onwards as disposable income increases. In other words, the figure suggests that the distribution of the VAT burden is regressive. ${ }^{36}$

In calculating the VAT burden distribution, disposable income is usually taken as the denominator. However, total consumer spending net of VAT is a better alternative because it varies less than income over the life cycle of the individual. Periods with lower incomes are generally followed by periods with higher incomes (students and temporarily unemployed people, for example) and the other way around (the elderly, for instance). Therefore, consumption expenditures are a more stable denominator than income is. If the VAT burden is expressed in terms of expenditures, its impact is

\footnotetext{
33 This article ignores the arguments for a higher-than-standard rate on luxury goods. The case for trying to increase the progressivity of the tax system in this way is weak even in developing countries (except with respect to big-ticket items such as cars, but then an excise would be a more appropriate instrument).

34 In addition, housing is excluded from the modeling, while VAT exemptions are simulated as zero rates.

35 The OECD / Korea Institute of Public Finance (2014) also find that reduced rates to address social, cultural (books, cinema, theater, concerts) and other non-distributional goals (hotel accommodation and restaurants) greatly benefit the rich both in aggregate terms and as a proportion of expenditure, so much so that the VAT rate actually has a regressive effect. In this connection, it should be noted though that the progressivity effect of applying the standard VAT rate to restaurants, for instance, must be balanced against the costs of the administrative complication of having to differentiate between on-premise and off-premise consumption. For an overview of earlier microdata-based studies of the distributional effect of consumption taxes, see box 2.1 in OECD / Korea Institute of Public Finance (2014).

36 In an analysis of the Polish VAT, Myck and Oczkowska (2015) find that the effective VAT rate ranged from $16.3 \%$ of income in the bottom decile to $6.8 \%$ in the top decile, a much more regressive outcome.
} 

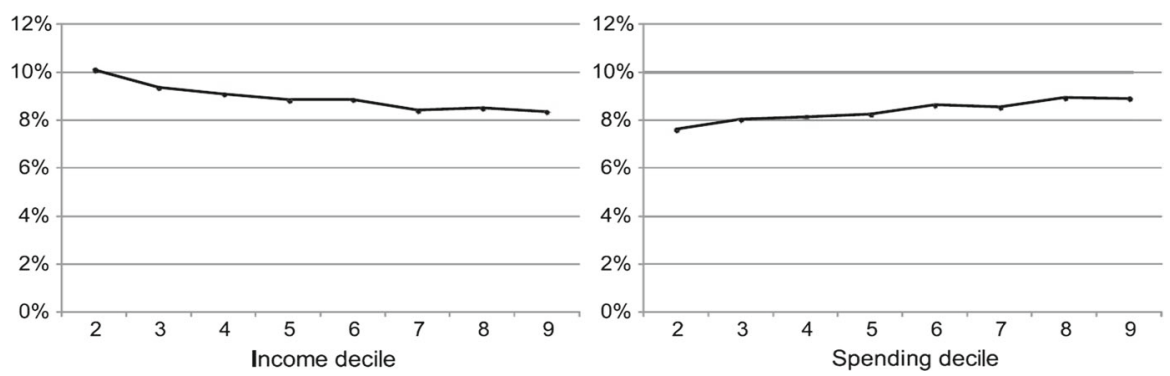

Fig. 2 The Netherlands: effective VAT rates across income and spending deciles. Source: Bettendorf and Cnossen (2015, p. 131)

slightly progressive in the Netherlands (see right panel of Fig. 2). Similar results have been found for other EU Member States (Institute for Fiscal Studies 2011).

Bettendorf and Cnossen (2015) also find that higher-income groups spend relatively as much on goods and services subject to the reduced rate as lower-income groups. This implies that they spend more in euro terms. In 2004, a Dutch household in the ninth decile spent 1.8 times more on reduced-rated goods per (equivalent) person than a household in the second decile (a similar relationship was found for the spending deciles). In other words, in euro terms, higher-income groups benefit nearly twice as much from the reduced rate as lower-income groups. Higher-income groups buy more expensive varieties of foodstuffs, eat out more often, throw more food away, buy more periodicals and books, and visit museums and concerts more often, etc. Consequently, the reduced rate is an ill-targeted instrument to mitigate the VAT burden on lower-income groups. Moreover, the revenue loss from having the lower rate is significant (more than $€ 8$ billion or nearly 1\% of Dutch GDP in 2010, ignoring behavioral effects), while the redistribution that is realized is small (see Fig. 2). As argued in the tax literature, the income tax and the social benefit system are much more effective alternatives for influencing the distribution of the tax burden. ${ }^{37}$

Last but not least, reduced rates involve a significant increase in administration and compliance costs, particularly if the VAT on differentially rated sales must be accounted for separately. Also, differentiated rates require additional audit oversight, increase refunds, give rise to various definitional problems and invite misclassification. Anomalies cannot be avoided, particularly if a distinction is made between foodstuffs consumed at home (taxed at the lower rate) and foodstuffs consumed in restaurants (taxed at the standard rate). ${ }^{38}$ Faced with such problems, the Netherlands, at the end of

\footnotetext{
37 For an early but still useful illustration of switching from the VAT to these alternatives, see Hemming and Kay (1981).

38 Cnossen (1999) cites the UK treatment of food, where the following factors have to be considered in applying the zero rate to food: place of consumption, timing of consumption, temperature, saltiness, number, volume, concentration, sweetness, use of fingers in consumption, and alcoholic content.

As another example, Canada taxes most restaurant sales at the standard rate, but its interaction with the zero rate for basic foodstuffs has led to rules that, according to Richard Bird in his comments on this article, 'seem to be as complex here as anywhere else ... [with] certainly high administrative and compliance costs. In establishments where most food and beverage sales (90\% or more) are taxable (for example, in restaurants, fast-food and take-out-and-delivery restaurants, snack bars, catering establishments, bars,
} 
the 1980s, moved all 'fancy' food products that had been taxable at the standard rate into the reduced-rate category used for most foods. ${ }^{39}$ Nonetheless, various anomalies linger on in nonfood sectors. ${ }^{40}$ Not surprisingly, Ebrill et al. (2001, pp. 68-69) note that $70 \%$ of the countries that introduced the VAT in the 1980s and 1990s opted for a single positive rate when doing so.

\section{Concluding observations}

This survey concludes with the following observations and suggestions. Generally, the flat-rate compensation scheme may have served a useful purpose in the past, but now it appears to have become an arbitrary form of input VAT relief within and between Member States. Consolidation and mechanization processes have made the sector much more capital-intensive, emphasizing the need for even-handed normal VAT treatment. This would also seem to apply to countries with relatively large numbers of small farms. Interestingly, Bulgaria and Romania tax their agricultural sector under normal arrangements, subject to a single threshold. This contrasts sharply with, say, Italy, which has 11 different flat rates (and five different thresholds), all without unambiguous justification. Beyond its use in the EU, the flat-rate scheme is not found in countries with modern VATs.

The author recommends, therefore, that the flat-rate schemes should be abolished. Outright abolition may be opposed politically, but a gradual phase-out could be achieved by not increasing compensation rates even though over time relatively more input VAT is being paid. The CAP can be used to compensate small farmers who might be unduly harmed by this measure. The next-best alternative to full taxation - that is, zero rating major agricultural inputs-is not recommended since registered farmers would not benefit from it and since normal taxation imposes some tax on exempt farmers selling at the farm gate or in tax-exempt local markets. In the same vein, to protect the integrity of the VAT, reduced rates on specified agricultural inputs should be abolished. Reduced rates are particularly objectionable in the case of products, including chemical fertilizers and pesticides, whose use can be harmful to the

\footnotetext{
Footnote 38 continued

lounges and mobile canteens), operators must collect the GST and the QST [Quebec Sales Tax] on all basic groceries sold. However, such foods and beverages are not taxable if sold in a form that does not allow them to be consumed immediately, considering the type of item (for example, an uncooked pizza), the quantity sold (for example, a one-liter container of ice cream), or its packaging. In establishments selling sweetened baked goods and similar products, operators must collect taxes on the items sold, with the exception of products that are not intended to be consumed on the premises and that are either prepackaged for sale to consumers in quantities of more than five single servings, or are not prepackaged but are sold in quantities of more than five single servings (for example, a whole pie)'.

What a mess! One wonders why we do these things to ourselves.

39 Previously, expensive meat was taxed at the reduced rate but expensive fish at the standard rate. Prepared meals were taxed at the reduced rate, but pancakes, fish and chips, and salads were taxed at the standard rate, unless they were consumed in hotels and restaurants, where they were taxed like all other foods at $6 \%$.

40 To give a few examples: books and newspapers are subject to the lower rate, but e-journals, tapes with spoken text and CDs are taxed at the standard rate; carriages and crutches for disabled people are taxed at the lower rate, but lifts and cars for the handicapped at the standard rate; and performances by circuses and zoos are subject to the lower rate, but services in recreation parks are taxed at the standard rate.
} 
environment. Admittedly, under the full taxation regime, subjecting these products to the standard VAT only has an externality-correcting effect on exempt farmers. To be fully effective, the harmful products should be subject to separate, non-rebatable excises.

The case for reduced VAT rates on foodstuffs is weak. In absolute money terms, higher-income people benefit more from them than lower-income groups-an odd way of helping the poor. Taxing foodstuffs under the standard rate would yield an amount of revenue much higher than would be needed to compensate the poor through the income tax and the social benefit system for the extra tax they have to pay. Application of the standard rate, practiced in Denmark and many other countries with a modern VAT, would also make it unnecessary to dwell on the difference between on-premise and off-premise consumption or between normal and luxury foods, which is difficult to delineate and monitor. In modern tax-and-expenditure systems, tax burden distribution concerns are addressed through the income tax and the social benefit system.

These conclusions should also be relevant for developing countries outside the EU and OECD fold, but some nuances may be noted. First, although the agricultural sector should be taxed, small (mostly illiterate) farmers (and other small businesses) should be exempted by setting the threshold rather high — at an amount equivalent to, say, US\$100.000. Secondly, the case for zero rating major agricultural inputs (chemical fertilizers, pesticides, and perhaps agricultural machinery) is stronger in developing countries than in developed economies, among others because the feasibility of making use of the registration option is smaller. Even then there is a case for levying differentiated externality-correcting excises on fertilizers and pesticides after the subsidies on these products have been removed. Thirdly, the case for exempting basic unprocessed foodstuffs is strong, because the income tax and the social security system are less equipped to compensate for the VAT's regressivity. However, the application of the zero rate to these or other foodstuffs is not recommended for administrative reasons.

Acknowledgements Sijbren Cnossen is grateful to Leon Bettendorf, Arjan Lejour, two anonymous referees, and, especially, to Richard Bird and Judith Payne for their comments on an earlier version of this article.

Open Access This article is distributed under the terms of the Creative Commons Attribution 4.0 International License (http://creativecommons.org/licenses/by/4.0/), which permits unrestricted use, distribution, and reproduction in any medium, provided you give appropriate credit to the original author(s) and the source, provide a link to the Creative Commons license, and indicate if changes were made.

\section{References}

Annacondia, F. (2015). VAT registration thresholds in Europe. International VAT Monitor 25/6. https:// www.ibfd.org/sites/ibfd.org/files/content/pdf/ivm_2015_06_int_1.pdf.

Barbone, L., Bird, R. M., \& Vazquez-Caro, J. (2012). The cost of VAT: A review of the literature. Working paper 12-22, International Center for Public Policy, Andrew Young School, Georgia State University.

Benedek, D., de Mooij, R., Keen, M., \& Wingender, P. (2015). Estimating VAT pass through. Working paper WP/15/214, Fiscal Affairs Department, International Monetary Fund.

Bettendorf, L., \& Cnossen, S. (2015). The long shadow of the European VAT, exemplified by the Dutch experience. FinanzArchiv, 71, 118-139.

Beugel, A. (2016). The special schemes for small enterprises and farmers in the EU VAT on the example of Germany. Master thesis, School of Economics and Management, Lund University, Sweden. 
Bird, R. M., \& Gendron, P.-P. (2007). The VAT in developing and transitional countries. Cambridge: Cambridge University Press.

Bocker, T., \& Finger, R. (2016). European pesticide tax schemes in comparison: An analysis of experiences and developments. Sustainability, 8, 378.

Cnossen, S. (1994). Administrative and compliance costs of the VAT: A review of the evidence. Tax Notes International 8/25, 1609-1626.

Cnossen, S. (1999). What rate structure for Australia's GST? The OECD experience. Tax Notes International, 24, 2137-2150.

Cnossen, S. (2015). Mobilizing VAT revenues in African countries. International Tax and Public Finance, 22, 1077-1108.

Common VAT Directive. (2006). Council directive 2006/112/EC of 28 November 2006 on the common system of value added tax. http://eur-lex.europa-eu/LexUriServ/LexUriServ.do?uri=OJ:L:2006:347: 0001:0118:en:PDF.

Crawford, I., Keen, M., \& Smith, S. (2010). Value added tax and excises. In J. Mirrlees, et al. (Eds.), Dimensions of tax design: The mirrlees review. Oxford: Oxford University Press.

Due, J. F. (1990). VAT treatment of farmers and small firms. In M. Gillis, C. S. Shoup, \& G. Sicat (Eds.), Value-added taxation in developing countries. Washington, DC: World Bank.

Ebrill, L., Keen, M., Bodin, J.-P., \& Summers, V. (2001). The modern VAT. Washington, DC: International Monetary Fund.

Ecker, T., Lang, M., \& Lejeune, I. (Eds.). (2012). The future of indirect taxation: Recent trends in VAT and GST systems around the world. Alphen aan den Rijn: Kluwer Law International BV.

EurActiv. (2016). French pork farmers accuse Germany of VAT fraud (3 February), as reported by Aline Robert and translated by Samuel White.

European Commission. (2014). The European union explained: Agriculture. Luxembourg: Publications Office of the European Union.

European Commission. (2016a). VAT thresholds (April). https://ec.europa.eu/taxation_customs/sites/ taxation/files/docs/body/vat_in_ec_annexi.pdf.

European Commission. (2016b). Compensation percentages applied by the member states under the common flat-rate scheme forfarmers (Update: May). https://ec.europa.eu/taxation_customs/sites/taxation/ files/docs/body/flat_rate_farmers_scheme_compensation_percentages_en.pdf.

European Commission. (2016c). VAT rates applied in the member states of the European Union. Situation at 1st August 2016. http://ec.europa.eu/taxation_customs/sites/taxation/files/resources/documents/ taxation/vat/how_vat_works/rates/vat_rates_en.pdf.

European Court of Justice. (2012). Case C-524/10. Commission v Portuguese Republic.

European Union. (2008). Treaty on the functioning of the European Union (TFEU). Official Journal of the European Union. http://eur-lex.europa.eu/legal-content/EN/TXT/PDF/?uri=OJ:C:2008:115:FULL\& from $=\mathrm{EN}$.

European Union. (2013). Agriculture in the European Union: Statistical and economic information. Report: Directorate-General for Agriculture and Rural Development.

Eurostat. (2016). Agriculture, forestry and fishery statistics (2015 ed.). http://ec.europa.eu/eurostat/docu ments/3217494/7158355/KS-FK-15-101-EN-N.pdf/79470e8cabf3-43d3-8cd4-84880962cdd4.

Evans, C. (2008). Taxation compliance and administrative costs: An overview. In M. Lang, C. Obermaier, J. Schuch, C. Staringer, \& P. Weninger (Eds.), Tax compliance costs for companies in an enlarged European community. London: Kluwer Law International.

García Azcárate, T. (1986). El impuesto sobre el valor añadido y la agricultura española: Unos primeros resultados, Hacienda Pública Española 99. a Azcárate (1986).

GATT. (1986). The general agreement on tariffs and trade. https://www.wto.org/english/docs_e/legal_e/ gatt47_e.pdf.

Harberger, A. C. (1964). Taxation, resource allocation, and welfare. In J. F. Due (Ed.), The role of direct and indirect taxes in the federal revenue system. Princeton, NJ: Princeton University Press.

Harberger, A. C. (1990). The uniform-tax controversy. In V. Tanzi (Ed.), Public finance, trade, and development. Detroit, MI: Wayne State University Press.

Hemming, R., \& Kay, J. A. (1981). The United Kingdom. In H. A. Aaron (Ed.), The value added tax: Lessons from Europe. Washington, DC: Brookings Institution.

IHS. (2011). The effect of VAT on price-setting behavior, in Institute for Fiscal Studies et al., A retrospective evaluation of elements of the EU VAT system. Report prepared for the European Commission, TAXUD/2010/DE/328. 
Institute for Fiscal Studies. (2011). Quantitative analysis of VAT rate structures, in Institute for Fiscal Studies et al., A retrospective evaluation of elements of the EU VAT system. Report prepared for the European Commission, TAXUD/2010/DE/328.

Institute for Fiscal Studies et al. (2011). A retrospective evaluation of elements of the EU VAT system. Report prepared for the European Commission, TAXUD/2010/DE/328.

Keen, M. (2013). The anatomy of VAT. National Tax Journal, 66, 423-446.

Myck, M., \& Oczkowska, M. (2015). Distribution of the VAT Burden in Poland by income group and demographic characteristics. Forum for Research on Eastern Europe and Emerging Economies (FREE): Policy Brief Series.

OECD. (2016). Consumption tax trends 2016: VAT/GST and excise rates trends and policy issues. Paris: OECD Publishing.

OECD/Korea Institute of Public Finance. (2014). The distributional effects of consumption taxes in OECD countries, OECD tax policy studies 22. Paris, France: OECD Publishing.

Schenk, A., Thuronyi, V., \& Cui, W. (2015). Value added tax: A comparative approach, Cambridge tax law series (2nd ed.). Cambridge: Cambridge University Press.

Tait, A. A. (1988). Value added tax: International practice and problems. Washington, DC: International Monetary Fund.

Terra, B., \& Kajus, J. (2015). Commentary—A guide to the recast VAT directive. Deventer: Kluwer Publishers.

UNDP. (2017). Taxes on pesticides and chemical fertilizers 1/4. http://www.undp.org/contents/sdfinance/ en/home/solutions/taxes-pesticides-chemicalfertilizers.html.

Weichenrieder, A. J. (2007). Survey of the taxation of small and medium-sized enterprises: Draft report on responses to the questionnaire. Paris: $\mathrm{OECD}$.

World Bank/PriceWaterhouseCoopers. (2016). Paying taxes 2017 (11th ed.).

WTO. (1994). Agreement Establishing the World Trade Organization. 